\begin{tabular}{|c|c|c|}
\hline \multirow[b]{2}{*}{ EVCDI I ENT } & Int.J.Curr.Microbiol.App.Sci (2021) 10(08): $456-458$ & IJCMAS \\
\hline & $\begin{array}{l}\text { International Journal of Current Microbiology and Applied Sciences } \\
\text { ISSN: 2319-7706 Volume } 10 \text { Number } 08 \text { (2021) } \\
\text { Journal homepage: http://www.ijcmas.com }\end{array}$ & 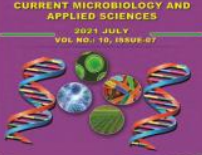 \\
\hline $\begin{array}{l}\text { LALELLEN } \\
\text { PUBLISHERS }\end{array}$ & & www. ijcmas.com \\
\hline
\end{tabular}

\title{
Invasive Potential of Listeria monocytogenes Isolated from Various Sources
}

\author{
Arul Pandiyan*, Mayuri Chelkar and Mahesh Dahake \\ Department of Veterinary Pathology, Nagpur Veterinary College, Maharashtra Animal and \\ Fishery Sciences University, Maharashtra, India \\ *Corresponding author
}

\section{A B S T R A C T}

Keywords

Listeria

monocytogenes, in vitro cell culture assay, Ptk cell line

Article Info

Accepted:

20 July 2021

Available Online:

10 August 2021
Listeria monocytogenes is a rod shaped, gram positive intracellular pathogen. It is a food-borne pathogen commonly spread by infestation with decaying vegetables, soils, animal faeces, sewage and water and is responsible for the zoonotic occurrence of human listeriosis. In this study, Listeria monocytogenes was isolated from varied sources including cheese, milk and milk products, vegetables, meat and sea food and human infections. These isolates were cultured and allowed to proliferate in brain heart infusion broth. Isolates were then screened for their invasive potential and ability to infect other cells in Ptk cell line by in vitro cell culture assay. Preparations were then observed under oil immersion and examined for intracellular Listeria monocytogenes. Amongst all isolates, human origin Listeria isolates showed highest invasive potential.

\section{Introduction}

Listeria monocytogenes is a gram positive, facultative anaerobic, non spore forming and rod shaped bacterium. In view of their tolerance to extremes of $\mathrm{pH}$, temperature and salt conditions, Listeria spps. is present ubiquitously in varied environment including food, soil and water, sewage, vegetables, milk, milk product, even in fish and fishery products (Graves et al., 2001). Listeriosis is an important bacterial zoonotic disease that occurs in variety of animals including humans.
It is responsible for the causation of human septicemia, meningitis, encephalitis in immunocompromised individuals and also causes miscarriage in pregnant women (Yamada et al., 2006). Gastrointestinal manifestations along with fever also occur.

The ubiquitous distribution of this pathogen and its ability to survive extremes of temperature changes makes its elimination from food extremely difficult (Almeida et al., 2008). Studies suggested that in vitro cell culture assay could be used as a preliminary 
test to identify the invasive potential of Listeria monocytogenes (Jiang et al., 2007). Pathogenesis of Listeria spps. is mainly due to the action of virulence genes including prfA, plcA, hly, actA located in Listeria pathogenicity island 1 (LIPI-1) and also other factors located outside the LIPI-1 which includes internalins. These help in the uptake of Listeria organisms by host phagocytes (Gregory et al., 1997).

Listeria monocytogenes are intracellular pathogens that are extremely invasive in nature, internalizing cells that are generally phagocytic. The ingested bacteria then uses several factors like Internalins, invasion associated protein, murein hydrolase protein and act A protein to invade host intestinal epithelium. The ingested bacterium then uses Listerolysin $\mathrm{O}$ (pore forming toxin) to digest the phagolysosomal membrane and multiply extensively in the host cell (Gaillard et al., 1987). These bacteria then disseminate in the host cytoplasm and cause the varied pathologic abnormalities (Indrawattana et al., 2011).

Despite being highly pathogenic at species level, Listeria monocytogenes is made of varied strains with differing invasive potential and pathogenicity. In vitro cell culture techniques are highly cost effective and efficient for evaluating Listeria monocytogenes invasive potential (Maklon et al., 2010). The aim of the present study is to demonstrate the in vitro invasive potential of Listeria monocytogenes which is directly attributed to its pathogenicity.

\section{Materials and Methods}

\section{Preparation of cover slips}

A single 12-mm round glass cover slip was picked up by the edge and immersed in $95 \%$ ethanol. It was briefly exposed to hot flame to remove excess of ethanol and then transferred to each well of 6 well tissue culture plates.

\section{Preparation of Ptk cells}

The Ptk cell line was grown in fresh $5 \mathrm{ml}$ DMEM [Dulbecco's Modified Essential Media, ThermoFisher Scientific] medium and also supplemented with $10 \%$ FBS[Fetal Bovine Serum, ThermoFisher Scientific]. The media was renewed every 1-2 days till confluency of $70-80 \%$ was achieved. The cells were then detached by scraping and plated into each well of 6 well tissue culture plate and incubated the plate at $37^{\circ} \mathrm{C}$ in $5 \% \mathrm{CO} 2$ incubator. The plates were monitored daily for formation of monolayer. Monolayer of Ptk cell was then trypsinized and was suspended in cold medium. Three $\mathrm{ml}$ of the split cells were plated into each well of 6 well tissue culture plate and incubated at $37{ }^{\circ} \mathrm{C}$ in $5 \% \mathrm{CO}$ 2 incubator.

\section{Preparation of Listeria monocytogenes culture}

Listeria monocytogenes isolated from varied sources was inoculated in BHI (Brain heart infusion) broth and allowed to grow overnight at $37^{\circ} \mathrm{C}$ in $5 \% \mathrm{CO} 2$ incubator. Turbidity value was adjusted to McFarlands tube 0.5. One $\mathrm{ml}$ broth culture was centrifuged at $1200 \mathrm{rpm}$ for 3 minutes and then the bacterial pellet was resuspended in $4 \mathrm{ml}$ RPMI (Roswell Park Memorial Institute Medium).

\section{Infection of the cells}

Five microlitre of test strain was plated to each cell culture well in duplicate and incubated for 2 hours at $37{ }^{\circ} \mathrm{C}$ in $5 \% \mathrm{CO}_{2}$. After incubation the wells were washed twice with PBS (Phosphate Buffer Saline) and then $1 \mathrm{ml}$ of RPMI ((Roswell Park Memorial Institute Medium) $+30 \mu \mathrm{g} / \mathrm{ml}$ gentamicin was added into each well. The plate was incubated at $37^{\circ}$ $\mathrm{C}$ in $5 \% \mathrm{CO}_{2}$ incubator for 30 minutes. Wells were then washed twice with PBS (Phosphate 
Buffer Saline). Using sterile forceps, cover slip was picked up by the edge. The cover slip was stained using Leishman's stain. Cover slip was air dried it was mounted on glass slide with cell-side down. Preparations were observed under oil immersion and evaluated for the intracellular Listeria monocytogenes.

\section{Results and Discussion}

The invasive potential of Listeria monocytogenes isolated from human origin source was significantly much greater as observed under oil immersion objective. The isolates from dairy and meat source showed significantly lesser invasive potential.

The present study was aimed to establish the invasive potential of Listeria monocytogenes bacterium in Ptk cell line derived from Potaroo rat kidney and assess their invasiveness. In vitro cell culture assay was carried out and the invasive potential produced by standard strain was used to compare with that of test isolates. It was observed that the invasiveness by human origin strains was higher than that of dairy and meat sources. Thus it establishes that in vitro plaque formation assay are suitable to assess the invasive potential of Listeria monocytogenes. Also, isolates obtained from human origin were highly invasive compared to dairy and meat origin isolates.

\section{References}

Almeida, P. F. and R. C. C. Almeida (2008) A PCR protocol using inl gene as a target for specific detection of Listeria monocytogenes. Food Control 11: 97-101.

Graves, L. M., Swaminathan, B. (2001). PulseNet standardized protocol for subtyping Listeria monocytogenes by macrorestriction and pulsed-field gel electrophoresis. Int J Food Microbiol.,65, 55-62.

Gregory S H., A. J.Sagnimeni and E. J.Wing (1997) Internalin B Promotes the Replication of Listeria monocytogenes in Mouse Hepatocytes. Infection and Immunity.65: 5137-5141.

Gaillard J. L., P. Berche, J. Mounier, S. Richard and P. Sansonetti (1987) In vitro model of penetration and intracellular growth of Listeria monocytogenes in human enterocyte- like Caco2. Infect. Immun. 55: 2822-2829.

Indrawattana N., T. Nibaddhasobon, N. Sookrung, M. Chongsa-nguan, A Tungtrongchitr, S. Makino, W. Tungyong and W. Chaicumpa (2011) Prevelance of Listeria monocytogenes in raw meats marketed in Bangkok and Charecterization of the isolates by phenotypic and molecular methods. J Health PopulNutr. 29: 26-38.

Jiang, 1., Chen, J., Xu, J. (2007). Virulence characterization and genotypic analyses of Listeria monocytogenes from food and processing environments in eastern China. International Journal of Food Microbiology, 121, 53-59.

Maklon K., A. Minami, A. Kusumoto, K. Takeshi and N. T. B. Thuy (2010) Isolation and Charecterization of Listeria monocytogenes from commercial asazuke (Japaneese light pickles). International Journal of Food Microbiology. 130: 134-139.

Yamada, F., Fukiko, U., Mariko, M., Hiroshi, S., Kunitoshi, O., Akikazu, F., Ryo, H. (2006). Invasion assay of Listeria monocytogenes using Vero and $\mathrm{CaCo} 2$ cells. Journal of Microbiological Methods., 66, 96-103.

\section{How to cite this article:}

Arul Pandiyan, Mayuri Chelkar and Mahesh Dahake. 2021. Invasive Potential of Listeria Monocytogenes Isolated from Various Sources. Int.J.Curr.Microbiol.App.Sci. 10(08): 456-458. doi: https://doi.org/10.20546/ijcmas.2021.1008.056 